\title{
Waste Generation and Management Practices in Residential Areas of Nigerian Tertiary Institutions
}

\author{
Amori, A. A ${ }^{1}$, Fatile B. $\mathrm{O}^{2}$, Ihuoma, S. $\mathrm{O}^{3}$ and Omoregbee, H.O \\ ${ }^{1}$ Mechanical Engineering Department, \\ Federal Polytechnic Ilaro, Ilaro, Ogun State, Nigeria. \\ ${ }^{2}$ Glass and Ceramic Department, \\ Federal Polytechnic Ado Ekiti, Ekiti State, Nigeria \\ ${ }^{3}$ Agricultural and Environmental Engineering Department, \\ University of Ibadan, Ibadan, Oyo State, Nigeria.
}

\section{Doi:10.5901/jesr.2013.v3n4p45}

\begin{abstract}
This study was carried out to assess the generation and management of solid wastes in residential areas of some selected tertiary institutions in southwest Nigeria, to provide insights into existing waste management approaches, so as to provide sustainable avenues for institutional policy improvement. It was conducted for a period of six months (J une to November 2012). The wastes were collected, sorted, weighed and classified according to their components. Also, questionnaires were administered to the unit heads in charge of waste management in the different institutions. The study shows that of the average waste generated per day in the residential areas of the institutions, food waste exhibited the highest percentage generation at $48 \%, 62 \%$ and $32 \%$ in the student, senior and junior staff residential areas, respectively. This was followed by plastic related materials with respective percentage generation at $18 \%, 7 \%$ and $19 \%$. Other important waste materials identified in the study include e-waste, metals and textiles. The results also revealed that high income earners generate more wastes than low income earners. The high composition of non-biodegradable wastes from these results bears implication of the requirement for alternative waste management solutions for sustainable and environmental friendly waste management system in the university community.
\end{abstract}

Key Words: Waste management, landfills, institutions, residential areas, environmental friendly.

\section{Introduction}

Solid wastes could be defined as non-liquid and nongaseous products of human activities, regarded as being useless (Babayemi and Dauda, 2009). It could take the forms of refuse, garbage and sludge (Leton and Omotosho, 2004). In developing countries such as Nigeria, open dumping of solid wastes into wetlands, watercourses, drains and burrow pit is a prevalent form of disposal. This practice has sometimes resulted in the littering of the surroundings, creates eyesore and odour nuisance (Ihuoma, 2012). Sangodoyin (1993) stated that open dumping of wastes serves as breeding place for flies, insects and rats. The proliferation of flies, insects and rats in the vicinity of a refuse dumpsite is due to the presence of putrescible components. The flies are capable of transmitting diseases through contact with food and water such as dysentery and diarrhea. The spread of rats to neighbouring house in the vicinity of refuse could be linked with diseases such as salmonellosis, leptospirosis and Lassa fever. The unsanitary mode of disposal of wastes, such as defecation in streams and the dumping of refuse in pits, rivers and drainage channels could be expected to affect surface and groundwater quality (Sangodoyin, 1991). Hence, the management 
and control of wastes at all stages of production, collection, transportation, treatment and ultimate disposal is a relatively social imperative (Salami et al, 2011). Afon (2007) observed that, little documentation of the quantity and composition of wastes generated in different areas of African cities, are limiting the capacity to develop effective waste management systems. Obviously, institutions in southwestern Nigeria are not exempted from the problem of solid waste generation and management. Based on these concerns, this paper sets out to characterize and quantify the solid wastes generated in different Nigerian institutions, in order to provide reliable data on the sources, types, composition and rate of generation of wastes for the implementation of sound waste management system.

\section{Materials and Methods}

\section{Study Sites}

The Study was conducted at three different tertiary institutions in south west Nigeria. The institutions are University of Lagos, Obafemi Awolowo University and University of Ibadan. These were randomly chosen as a true representative of all tertiary institutions spread within the southwestern geopolitical zone of Nigeria. The University of Lagos lies on latitude $6^{\circ} 30.40^{\prime} \mathrm{N}$ and $3^{\circ} 24.52$ 'E longitude (Ayolabi, 2004), while Obafemi Awolowo University covers over 9,000 hectares of land lying approximately within longitudes 4_30'E and 4_34'E and latitude 7_29' $\mathrm{N}$ and 7_33' $\mathrm{N}$ (Baloye, et al., 2010) and that University of I badan is located on latitude $3^{0} .5^{1} \mathrm{E}$ and longitude $7^{0} \cdot 12^{1} \mathrm{~N}$ (Omoleye, 2009).

\section{Materials and Methods}

The questionnaires which were used in the collection of the require information were structured into two categories. The two categories include questionnaire for the unit in charge of waste management of campus and questionnaire for students and staffs residing on campus. Alongside with the questionnaire administration, photographs of the various disposal points, major dump sites, waste collection equipment and sewage treatment plant were obtained.

The methodology involves direct waste sampling and analysis approach given by Brunner \& Ernst, (1986) and reported by Moore, et al, (1994) as well as waste characterization method of Bernache-Perez, et al, (2001) given by Bamgboye and Ojolo, (2004) which was employed and described by Oyelola and Babatunde, (2008) was used in this study. The approach involves sampling from a particular waste stream and manually sorting it into its material types. Generated solid waste samples were obtained from bins and waste disposal sites, before the delivering of the waste materials to landfills by the institutions' operated trucks disposal systems, from the administrative, commercial, faculty and departmental buildings of the universities. In the residential buildings, samples were taken from individual households to develop waste composition data for the specific types of buildings to achieve a system of source generator-based study. The waste characterization study was carried out for five days on each of the study area and the average of wastes taken in kg per day, to even out encountered irregularities in the waste generations. These monitoring was carried out over a period of six months (J une to November 2012).

\section{Results and Discussions}

\section{Solid Waste Generation in the Institutions}

The quantity and rate of solid waste generation in the institutions were estimated. The average mass-based compositions of the characterized wastes in the different sites studied in the institutions are presented below. 


\section{Composition of Solid Wastes from the Halls of Residence}

The results of the field work comprised the average values of the mass-based composition of waste materials generated in the halls of residence, the total quantity of waste generated from the institutions' halls of residence and the percentage composition of the wastes are presented in table 1 and figure 1 respectively.

Figure 1 revealed that food wastes constitute the highest proportion of wastes generated $(46 \%)$ from the halls of residence in the institutions. The higher proportion of putrescible food waste could be responsible for the inherent odour problems arising from most of the refuse transfer depots in the halls of residence. Nylon/polythene bags constitute the second highest proportion (13\%) of the wastes. The high quantity of nylon bags (predominantly pure water sachets) further confirms the work of Ihuoma (2011) that most students in the halls of residents patronize sachet water because they believe that their water supply is not suitable for drinking. The other waste materials generated include; plastic $5 \%$, paper $4 \%$, sanitary wastes and hairs $6 \%$ each, sand $7 \%$, cans/tins $2 \%$, e-waste, textiles and glass $1 \%$ each, while other unclassified components were $8 \%$.

The total quantity of wastes generated from the halls of residents in the institutions was estimated using information on the total number of students resident in the different halls of residents of the universities and their per capita waste generation rates. Hence, the total quantity of waste generated from the halls of resident in the institution is estimated at $4373.4 \mathrm{~kg} / \mathrm{day}$.

Table 1: Composition of Wastes from the Institutions' Halls of Residence

\begin{tabular}{ll}
\hline Waste Materials & $\begin{array}{l}\text { Total Quantity of } \\
\text { Wastes (kg/day) }\end{array}$ \\
\hline Paper & 207.39 \\
Food & 2100.45 \\
Plastic & 213.36 \\
Glass & 54.15 \\
Cans/Tins & 109.11 \\
Textiles & 28.74 \\
Nylon & 586.17 \\
Sand & 279.12 \\
e-waste & 29.16 \\
Hairs & 254.13 \\
Sanitary Waste & 239.91 \\
Others & 271.71 \\
Total & 4373.4 \\
\hline
\end{tabular}




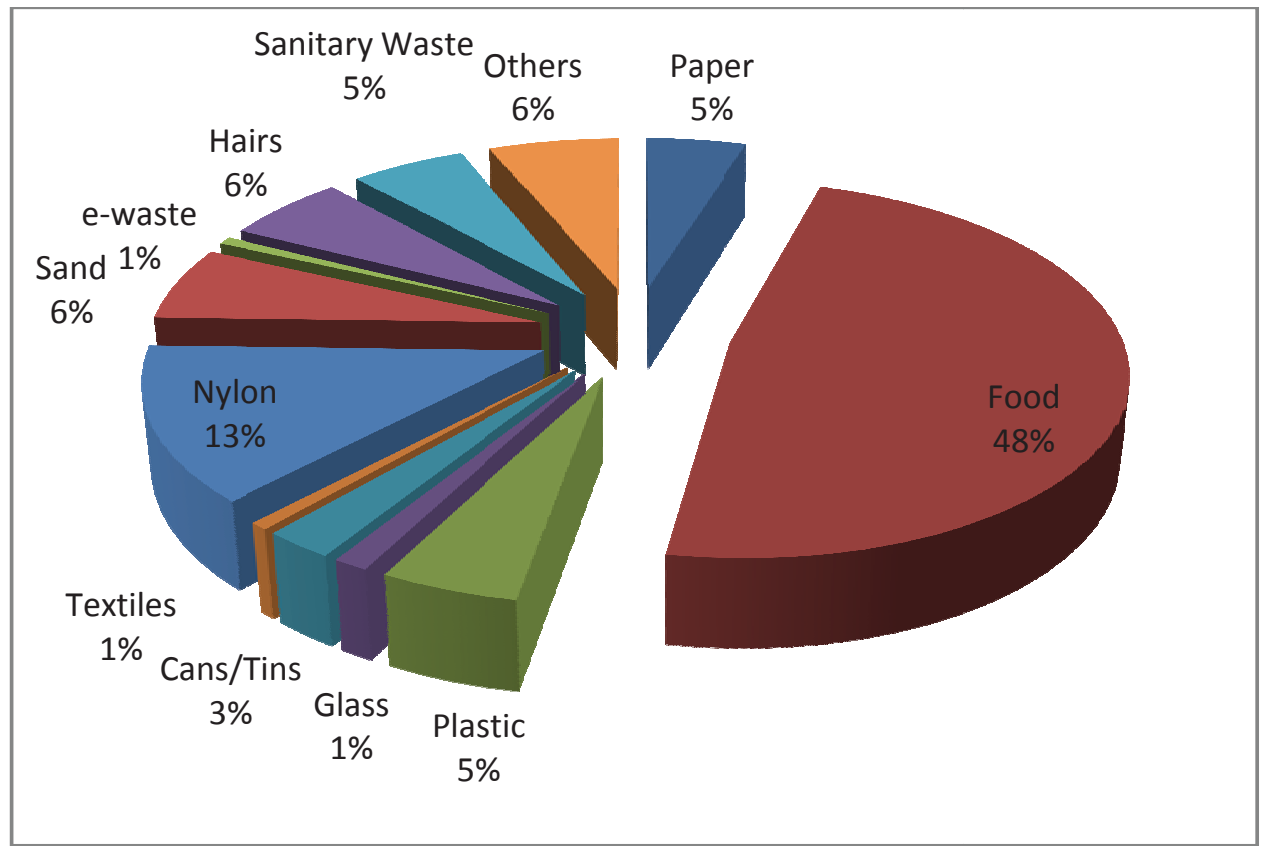

Fig. 1: Percentage Composition of Wastes from the Halls of Residence

Table 2: Average Composition of Wastes from the Institutions' Staff Residential Quarters

\begin{tabular}{lll}
\hline Waste Components & $\begin{array}{l}\text { Senior Staff } \\
(\mathbf{K g} / \text { day) }\end{array}$ & $\begin{array}{l}\text { Junior Staff } \\
\text { (Kg/day) }\end{array}$ \\
\hline Paper & 0.708 & 0.504 \\
Food & 3.636 & 1.152 \\
Plastic & 0.105 & 0.522 \\
Glass & 0.114 & 0.036 \\
Metals & 0.078 & 0.069 \\
Wood & 0.003 & 0.048 \\
Textiles & 0.057 & 0.378 \\
Nylon/Polythene & 0.291 & 0.15 \\
Sweepings & 0.096 & 0.201 \\
Others & 0.756 & 0.504 \\
Total & 5.844 & 3.564 \\
\hline
\end{tabular}

\section{Composition of Waste from the Staff Residential Quarters}

Table 2 shows the composition of the wastes in the staff residential quarters in the institutions. It reveals that higher amount of wastes are generated from the senior staff quarters compared to 
that from the junior staff quarters. The result shows that, per household waste generation rate in the junior and senior staff quarters of the institution ranges from $3.564 \mathrm{~kg} /$ household/day to 5.844 $\mathrm{kg} /$ household/day respectively. This conforms with previous studies that linked municipal solid waste generation rate to the level of income; hence, high income earners generate more wastes than the low income earners.

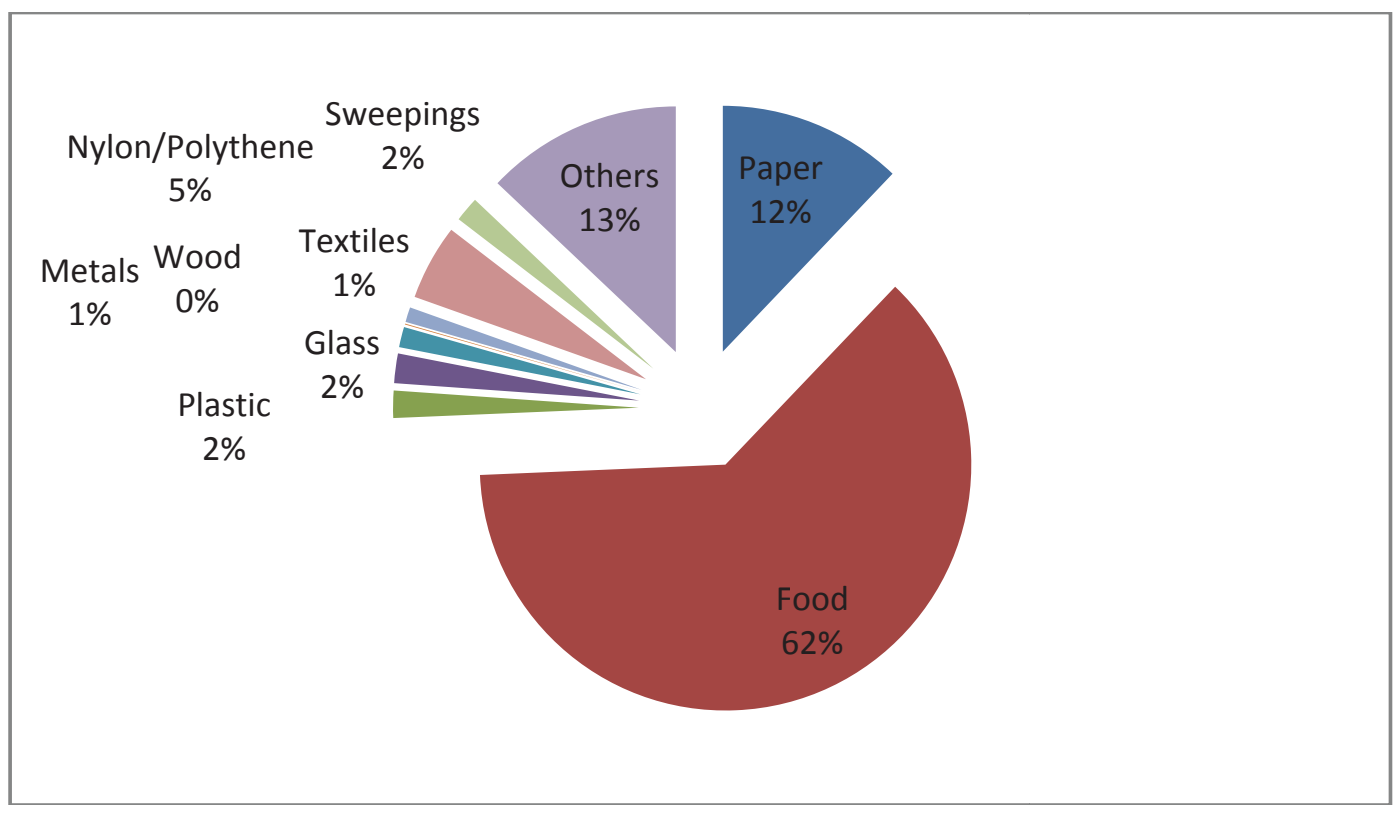

Fig. 2: Percentage Composition of Wastes from the Senior Staff Residential Areas

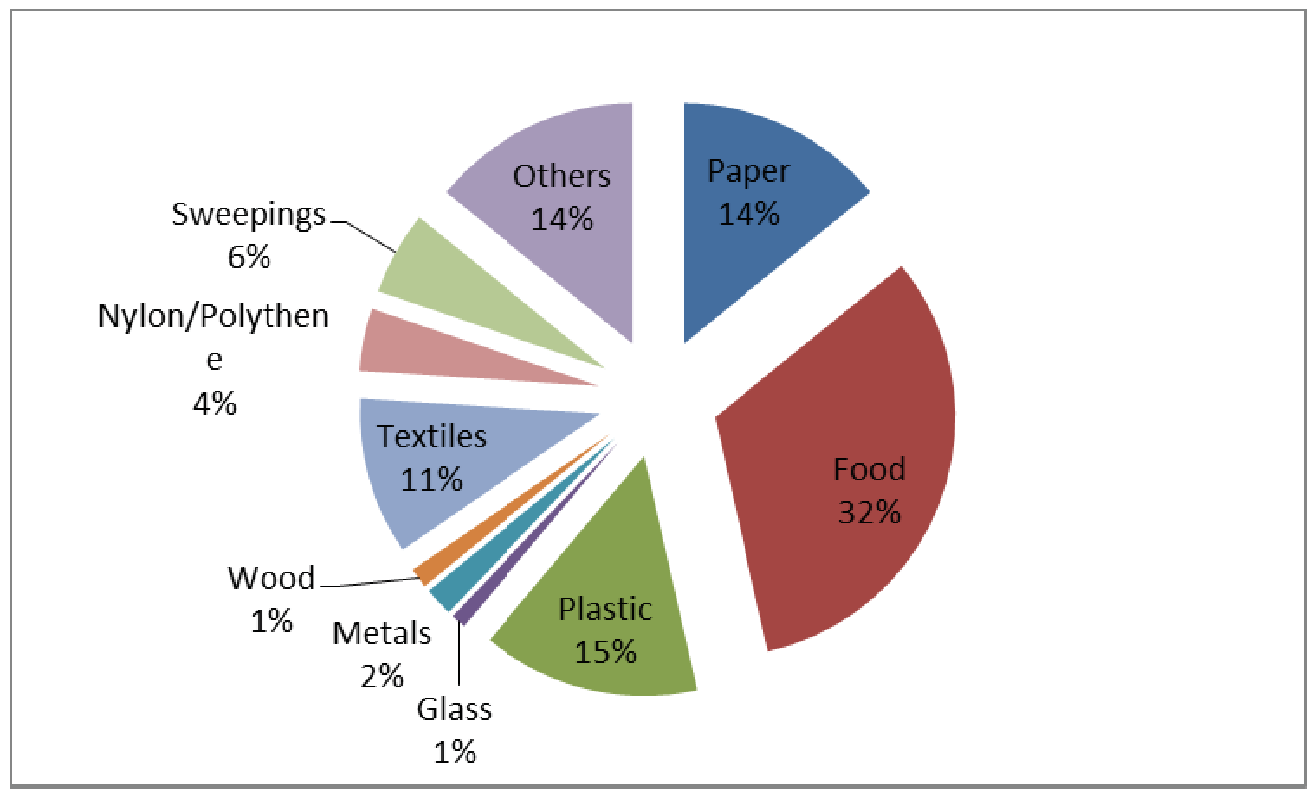

Fig. 3: Percentage Composition of Wastes from the Junior Staff Residential Areas 
Also, figures 2 and 3 show the percentage composition of wastes from the senior and junior staff residential quarters respectively. Food/fruit wastes accounted for the greatest volume of waste in the senior staff quarters, with $62 \%$ when compared with $32 \%$ in the junior staff quarters. This could be as a result of their high purchasing power. The volume of waste produced in the senior staff areas is almost double of those from the junior staff area and hence have more thrown away food.

Another very important waste was paper which decreased from senior staff areas to junior staff areas with average weight of 0.708 to $0.504 \mathrm{~kg} / \mathrm{household} /$ day respectively. A similar study have recorded more paper waste in the high income areas, an indication that the high income earners are mostly literate and uses papers in most of their daily activities (Alfred and Sangodoyin, 2011). Papers are mainly used in the low income areas for food packaging.

The junior staff generate more of textile/clothing materials as compared to senior staff. This could be because the high income earners buy high quality materials and sometimes give them out to the low income class, while the low income earners patronize a low quality and fairly used materials.

Also, the junior staff areas generate wood wastes resulting from the use of wood for coking unlike the senior staff areas where kerosene and cooking gas are used for cooking. Similarly, the proportion of waste classified as "Others" which is $14 \%$ in the junior staff areas include ash, dust, sand and soil generated during house cleaning.

\section{Conclusion and Recommendations}

Characterisation of solid wastes generated in residential areas of southwestern institution in Nigeria has been carried out in this work. The waste characterisation identified food wastes as having the highest average waste material of $48 \%, 62 \%$ and $32 \%$ in the student, senior and junior staff residential areas, respectively. This was followed by paper wastes and plastic related materials, in the form of polythene bag, plastic bottles, plastic food pack and polystyrene food pack. Other important waste materials identified in the study include e-waste, metals and textiles. The results also revealed that high income earners generate more wastes than low income earners. This agreed with previous studies that the quantity and rate of solid waste generation in an area depends on the population, socio-economic status of the citizens and the kinds of commercial activities predominant in the area.

The high composition of non-biodegradable wastes from these results bears implication of the requirement for alternative waste management solutions for attaining sustainable and environmental friendly waste management system in the institutions. Such sustainable waste management scheme should include the development of bio-gasification scheme for reducing the biodegradable waste components and any of recycling, co-incineration, pyrolysis and gasification system to be employed for reducing the non biodegradable waste components.

\section{References}

Afon, A. O. (2007). An Analysis of Solid Waste Generation in Traditional African City, the Example of Ogbomosho, Nigeria. Environment and Urbanization, Volume 19, pp. 527-537.

Alfred, J. N. and Sangodoyin, A. Y. (2011). A Comparative Analysis of Municipal Solid Waste Generation Rate and Characteristics between High and Low Income Earners in Maiduguri, Nigeria. Journal of Scientific and Industrial Studies, Volume 9, pp. 106-109

Ayolabi, E.A. (2004). Seismic Refraction Survey of University of Lagos, Nigerian and its Implication. Journal of Applied Science. 7(3): 4319-4327.

Babayemi, J. O. and Dauda, K. T. (2009). Evaluation of Solid Waste Generation, Categories and Disposal Options in Developing Countries: A Case Study of Nigeria. Journal of Applied Science and Environmental Management, Vol. 13(3): pp.83 - 88. 
Baloye, D. O., Adesina, F. A and Kufoniyi, O. (2010): A spatial decision support system approach to sustainable physical development planning. Journal of Geography and Regional Planning. Vol. 3(9), pp. 219-233.

Bamgboye, A. I. and Ojolo, S. J. (2004). Characterization of Municipal Solid Wastes being Generated in Lagos State, Nigeria. LAUTECH Journal of Engineering and Technology, Volume 2 pp. 36-38.

Bernache-Perez, G., Sanchez-Colon, S., Garmendia, A. M., Dávila-Villarreal, A. and Sánchez-Salazar, M. E. A. (2001). Solid Waste Characterization Study in the Guadalajara Metropolitan Zone, Mexico. Waste Management \& Research, Vol. 15: pp. 573-583.

Brunner, P.H. and Ernst, W.R. (1986). Alternative Methods for the Analysis of Municipal Solid Waste. Waste Management and Research. Vol. 4, pp. 147160.

I huoma, S. O. (2012). Characterization and Quantification of Solid and Liquid Wastes Generated at the University of I badan, I badan, Nigeria. MSc. Thesis Presented to the Department of Agricultural and Environmental Engineering, University of I badan, Ibadan, Nigeria.

Ihuoma, S. O. (2011). Assessment of water needs in University of Ibadan Campus. An Unpublished Seminar Work Presented to the Department of Agricultural and Environmental Engineering, University of I badan.

Leton, T. G. and Omotosho, O. (2004). Landfill Operations in the Niger Delta Region of Nigeria. Engineering Geology 73(1-2): 171-177.

Moore, S., Grime, P. and King, B. (1994). Urban Solid Waste Characterization. CRC for Waste Management and Pollution Control Ltd, Australia.

Omoleye, A. A. (2009). "Field Accumulation Risks of Heavy Metals and uptake effects on the biology of Sitophilus zeamails (Coleoptera: Currculionidea)' Journal of African Scientist. Vol. 10, No. 2, pp. 75.88.

Oyelola, O. T. and Babatunde, A. I. (2008). Characterization of Domestic and Market Solid Wastes at Source in Lagos Metropolis, Lagos, Nigeria. African Journal of Environmental Science and Technology. Volume 3 pp. 430-437.

Salami, L., Susu, A. A., Patinvoh, R. J. and Olafadehan, O.A. (2011). Characterization Study of Solid Wastes: A Case of Lagos State. International Journal of Applied Science and Technology, Volume 1 (3): pp. 47-52.

Sangodoyin, A. Y. (1993). Consideration on Contamination of Groundwater by Waste Disposal System in Nigeria: Environmental Technology. Vol. 14 (10): pp. 957-964.

Sangodoyin, A. Y. (1991). Ground and Surface Water Pollution by Open Dump in Ibadan, Nigeria. Discovery and Innovation. Vol. 2 (1): pp. 37-43. 
